\title{
Pengembangan Media Pembelajaran Kurikulum 2013 di Kelas IV Tema 9 Subtema 1
}

\author{
Indri Anugraheni, Firosalia Kristin \\ indri.anugraheni@staff.uksw.edu, firosalia.kristin@staff.uksw.edu \\ PGSD, Universitas Kristen Satya Wacana
}

The Development Of Learning Media For 2013 Curriculum In IV Grade Theme 9 Subtheme 1

\begin{abstract}
The purpose of this study is to develop 2013 Curriculum-based learning media. This type of research is development research. The data analysis technique used in this study is to perform instrument validation in accordance with the criteria of the learning instrument validation indicator and then describe the results of data analysis. The product produced from this development research is 2013 Curriculum-Based Learning Media. The results of the analysis shows that the learning media developed in the sub-theme "My food is healthy and nutritious" learning 1, learning 2, learning 3, learning 4, learning 5, and learning 6 are in "Very Good" category.
\end{abstract}

Keywords: learning media, 2013 curriculum

Received date: 31 Agustus $2018 \quad$ Revised date: 20 September 2018 Accepted date: 21 September 2018

\section{PENDAHULUAN}

Pendidikan mempunyai peranan penting dalam perkembangan suatu bangsa. Pendidikan yang ada di Indonesia mulai tingkat dasar hingga perguruan tinggi. Pendidikan bertujuan untuk menguasai pengetahuan (kognitif), kemampuan sosial, kemampuan dalam bekerja serta pengembangan kepribadian. Untuk dapat mencapai tujuan pendidikan maka diperlukan pengembangan kemampuankemampuan yang ada dengan menggunakan berbagai metode dan alat yang inovatif. Pendidikan saat berkaitan dengan kurikulum. Komponen-komponen kurikulum terdiri dari tujuan, metode, bahan ajar, media, dan sebagianya.

Sitepu (2012) menyatakan bahwa kurikulum adalah suatu alat yang diguankan untuk mencapai pendidikan serta pedoman pelaksanaan bagi semua jenjang pendidikan. Tahun 2013 pemerintah Indonesia merancang kurikulum 2013 sebagai langkah lanjutan dari pengembangan kurikulum KTSP. Indonesia sudah menggunakan sistem kurikulum dalam penyelenggaraan pendidikan baik di tingkat dasar hingga perguruan tinggi.

Kurikulum 2013 dikembangkan dengan basis kompetensi. Kurikulum 2013 sangat diperlukan dalam pembelajaran sebagai instrument untuk mengarahkan peserta didik menjadi: 1) manusia berkualitas yang mampu aktif dan produktif menjawab tantangan zaman yang selalu berubah; 2) manusia terdidik yang beriman dan bertaqwa kepada Tuhan Yang Maha Esa, berakhlak mulia, sehat, berilmu, cakap, kreatif, mandiri; 3) warga Negara Indonesia yang demokratis, beranggung jawab (Kemendikbud, 2014:2).

Perangkat pembelajaran merupakan bagian yang penting dalam kegiatan belajar mengajar. Trianto (2010:96) menyatakan bahwa perangkat pembelajaran adalah perangkat pembelajaran yang digunakan guru dalam proses pembelajaran yang meliputi buku peserta didik, buku guru, silabus, program semester, RPP, LKS, soal tes hasil belajar atau soal evaluasi dan media pembelajaran. Perangkat pembelajaran yang digunakan dalam pembelajaran disusun dan dikembangkan oleh guru dan pakar pendidikan. Pembuatan perangkat pembelajaran (berupa silabus, Media, RPP, LKS) dapat dikembangkan sesuai dengan kebutuhan dan kemampuan masing-masing siswa yang ada di sekolah. Pengembangan perangkat pembelajaran bagi siswa yang berada di pedalaman akan berbeda dengan siswa yang berada di kota. Oleh karena itu dapat disimpulkan bahwa perangkat pembelajaran adalah semua perlengkapan belajar yang digunakan oleh pendidik/guru dalam proses kegiatan belajar 
mengajar yang berupa Silabus, Program semester, RPP, bahan ajar, Lembar Kegiatan Siswa (LKS), dan evaluasi belajar.

Berdasarkan hasil observasi dan wawancara dengan guru-guru yang ada di gugus joko tingkir Salatiga menyatakan bahwa dalam kegiatan pembelajaran belum menggunakan media pembelajaran secara optimal dan media yang digunakan belum inovatif. Guru mengakui, bahwa media pembelajaran merupakan alat yang sangat penting dalam pembelajaran untuk menumbuhkan minat dan mengaktifkan siswa dalam proses pembelajaran. Banyak faktor yang menjadi kendala guru terkait pengembangan media yaitu: faktor waktu, biaya, kemauan dan kreativitas yang masih kurang. Bertolak dari hasil observasi maka peneliti melakukan pengembangan media pembelajaran kurikulum 2013 tema makananku sehat dan bergizi di kelas IV.

\section{KAJIAN PUSTAKA}

Trianto (2010: 96) menyatakan bahwa perangkat pembelajaran merupakan perangkat yang digunakan dalam proses pengelolaan pembelajaran yang terdiri dari silabus, RPP, media pembelajaran, buku siswa, buku guru dan lembar penilaian. Perangkat pembelajaran dalam penelitian ini difokuskan pada pengembangan media pembelajaran sesuai dengan kebutuhan di lapangan. Perangkat pembelajaran yang dikembangakn berupa media pembelajaran kurikulum 2013 harus sesuai dengan tingkat kemampuan peserta didik. Maka dapat disimpulkan bahawa Perangkat pembelajaran adalah semua perangkat (silabus, bahan ajar, media, buku siswa, RPP, LKS) yang dikembangkan, disusun dan dirancang oleh pakar pendidikan untuk kegiatan proses belajar mengajar yang dilakukan oleh guru.

Kata Media berasal dari bahasa Latin yang berarti 'tengah', 'perantara', atau 'pengantar'. Dalam kegiatan proses belajar mengajar, media diartikan sebagai alat-alat grafis, photografis, atau elektronik untuk menangkap, memproses, dan menyusun kembali informasi visual atau verbal. Secara umum media pembelajaran adalah alat bantu dalam proses belajar mengajar (Saputro \& saputra, 2015:156). Sardiman (1996:5) menyatakan bahwa media pembelajaran adalah paduan antara alat dan bahan atau perpaduan antara hardware dan software. Hal ini sejalan dengan pendapat Muhson (2010:2) yang menyatakan media pembelajaran merupakan bagian dari sumber belajar yang merupakan kombinasi antara perangkat lunak (bahan belajar) dan perangkat keras (alat belajar). Maka disimpulkan bahwa media pembelajaran adalah alat yang digunakan oleh pendidik dalam proses atau kegiatan sebagai perantara untuk mencapai tujuan dari pembelajaran. Oleh karena itu media pembelajaran dipahami sebagai alat komunikasi antara pendidik (guru) dan sisw.

Batubara (2018:15) menyatakan bahwa kehadiran media pembelajaran sangat membantu siswa yang sedang dalam tahapan fase operasional konkret dalam memahami materi yang bersifat abstrak atau kurang mampu dijelaskan dengan menggunakan bahasa verbal. Hal ini juga sependapat dengan pendapat Lailiyah \& Sukartiningsih (2018:1151) yang menyatakan bahwa media pembelajaran merupakan alat yang digunakan guru untuk membantu guru menyampaikan sebuah materi atau informasi pada siswa sehingga dapat lebih mudah dipahami oleh siswa. Pendapat tersebut juga sejalan dengan yang dikemukan oleh Fransisca (2018:1917) bahwa penggunaan media pembelajaran membantu untuk menyampaikan informasi atau pesan kepada siswa agar lebih mudah dipahami dan menarik perhatian siswa agar lebih fokus saat mengikuti pembelajaran, jadi media pembelajaran sangatlah berpengaruh untuk mengaktifkan dan meningkatkan hasil belajar siswa. Ketiga pendapat tersebut didukung dengan pendapat Mawardi (2018:31) yang menyatakan bahwa media pembelajaran hakikatnya sesuatu yang dapat digunakan sebagai sarana untuk menyalurkan pesan dan informasi materi pembelajaran sehingga dalam diri siswa terjadi proses belajar dalam rangka mencapai tujuan.

Undang-Undang Nomor 20 Tahun 2003 tentang Sistem Pendidikan Nasional menjelaskan bahwa kurikulum adalah seperangkat rencana dan pengaturan mengenai tujuan, isi, dan bahan pelajaran serta cara yang digunakan sebagai pedoman penyelenggaraan kegiatan pembelajaran untuk mencapai tujuan pendidikan tertentu. Berdasarkan pengertian tersebut, ada dua dimensi kurikulum yaitu: pertama tentang peraturan dan rencana mengenai tujuan, isi, dan bahan pelajaran, sedangkan yang kedua adalah langkah-langkah atau cara yang digunakan untuk proses kegiatan pembelajaran. Kurikulum 2013 yang diberlakukan saat ini mulai tahun ajaran 2013/2014 memenuhi kriteria kedua dimensi tersebut. 
Kurikulum 2013 yang dirancang dengan karakteristik sebagai berikut: 1) Mampu mengembangkan keseimbangan antara sikap spiritual dan sikap sosial, pengetahuan (kognitif), dan keterampila (psikomotorik), serta menerapkannya dalam berbagai situasi di lingkungan sekolah dan lingkungan masyarakat; 2) Mampu menempatkan sekolah sebagai bagian dari lingkungan masyarakat yang memberikan pengalaman belajar kepada peserta didik sehingga peserta didik mampu menerapkan apa yang dipelajari baik di lingkungan sekolah maupun lingkungan masyarakat dan memanfaatkan lingkungan masyarakat sebagai sumber belajar; 3) Mampu emberi waktu yang cukup untuk mengembangkan berbagai sikap (afektif), pengetahuan (pengetahuan), dan keterampilan (psikomotorik); Mampu mengembangkan kompetensi yang dinyatakan dalam bentuk Kompetensi Inti kelas yang dirinci unsur pengorganisasi (organizing elements) Kompetensi Dasar. Semua Kompetensi Dasar dan proses pembelajaran mampu dikembangkan untuk mencapai kompetensi yang dinyatakan dalam Kompetensi Inti; 5) Mampu mengembangkan Kompetensi Dasar berdasar pada prinsip akumulatif, saling memperkuat (reinforced) dan memperkaya (enriched) antar-mata pelajaran dan jenjang pendidikan (organisasi horizontal dan vertikal).

\section{METODE PENELITIAN}

Jenis penelitian yang digunakan dalam penelitian ini adalah penelitian pengembangan. Penelitian ini mengembangkan perangkat pembelajaran yang berupa media pembelajaran kurikulum 2013 kelas IV Tema Makananku Sehat dan Bergizi. Pada penelitian ini dibatasi sampai dengan uji coba terbatas untuk mengetahui kualitas media pembelajaran yang dikembangkan dan untuk membantu guru dalam mengajarkan materi tema maknaanku sehat dan bergizi pada siswa kelas IV. Objek penelitian ini adalah media pembelajaran tema makanan sehat dan bergizi. Prosedur pengembangan yang digunakan dalam penelitian ini adalah prosedur pengembangan menurut Sugiyono. Berikut ini adalah prosedur pengembangan Produk:

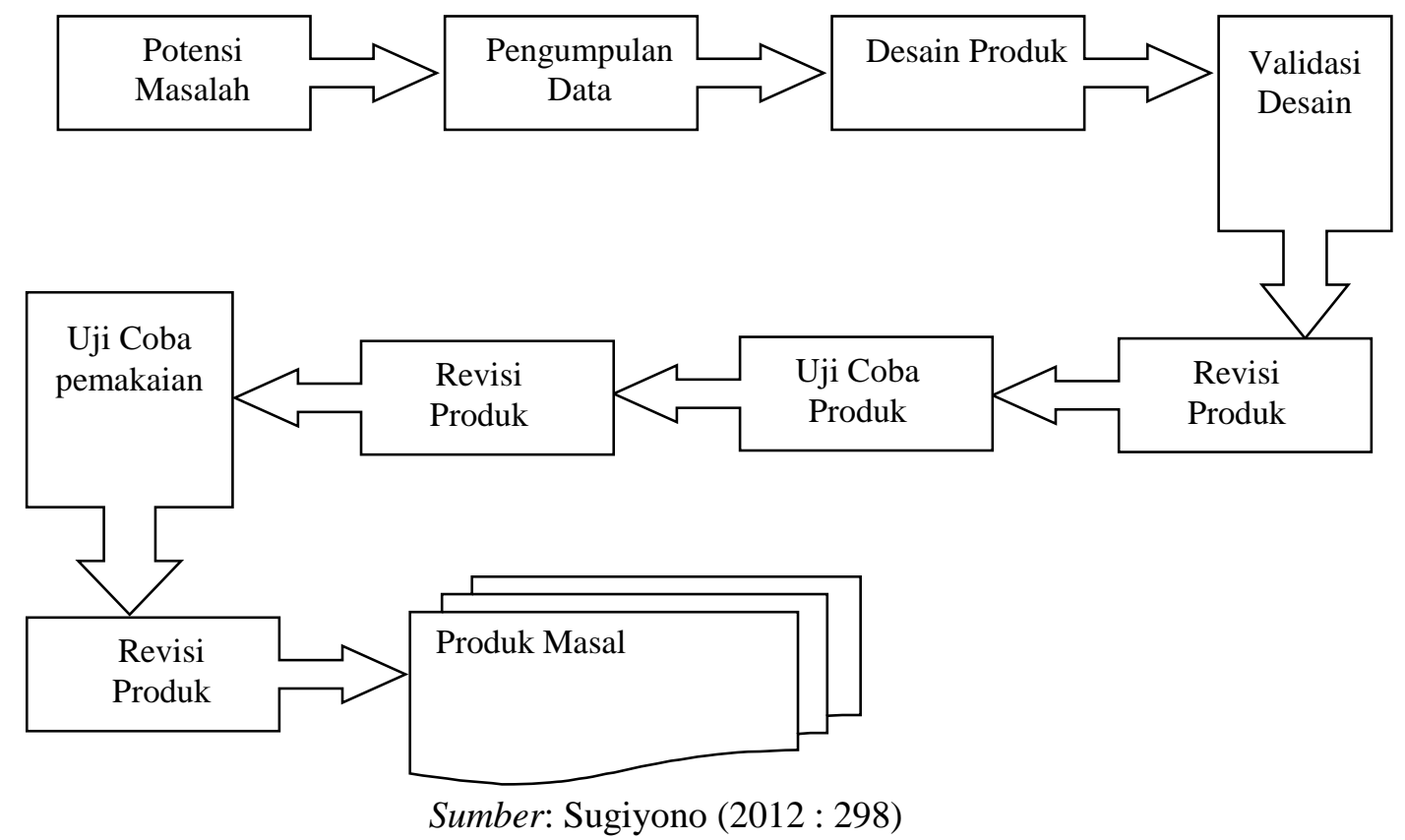

Gambar 1.

Prosedur Pengembangan Produk

Gambar 1 menunjukan prosedur pengembangan produk (media pembelajaran) menurut Sugiyono. Sugiono $(2012 ; 298)$ berpendapat bahwa penelitian berawal adanya masalah atau potensi yang terjadi di lapangan. Setelah masalah atau potensi dapat ditunjukkan secara faktual atau krusial, maka selanjutnya dilakukan teknik pengumpulan data. Pengumpulan data dilakukan untuk mendapatkan informasi yang akurat dan cukup untuk melakukan penelitian pengembangan. Informasi atau data-data yang diperoleh digunakan untuk perencanaan produk yang dikembangkan khususnya pengembangan media pembelajaran. Produk yang dihasilkan perlu didesain terlebih dahulu. Desain 
produk yang dikembangkan dalam bidang pendidikan mempunyai tujuan untuk meningkatkan produktivitas pendidikan, yaitu lulusan yang jumlahnya sangat banyak, berkualitas, dan relevan dengan kebutuhan (Sugiyono, 2010: 412). Penelitian pengembangan media pembelajaran berbasis kurikulum 2013 yang dikembangkan ini hanya sampai pada uji coba terbatas. Hal ini dikarenakan waktu penelitian yang kurang sehingga tidak sampai pada pengembangan produk masal. Oleh karena itu, peneliti berencana akan melanjutkan penelitian ini ditahun kedua.

Tahapan selanjutnya melakukan validasi desain (media pembelajaran) yang merupakan proses kegiatan untuk menilai produk yang dihasilkan yaitu produk media pembelajaran. Penilaian produk media pembelajaran dilakukan oleh pakar pendidikan yaitu Ahli pendidikan dari UKSW, ahli pendidikan dari luar UKSW dan Praktisi (Guru SD gugus Joko Tingkir). Perbaikan desain perlu dilakukan untuk memperbaiki kekurangan dari produk yang didesain. Selanjutnya adalah tahapan uji coba produk. Dalam bidang pendidikan, desain produk dapat langsung diujicobakan setelah dilakukan validasi dan revisi desain produk. Setelah diujicobakan, tahap selanjutnya adalah revisi produk kemudian dilakukan uji coba pada kelas yang lebih besar. Apabila ditemukan kelemahan dan kekurangan maka produk direvisi kembali. Jika kekurangan dan kelemahan dapat diselesaikan maka produk dapat di produksi secara masal.

Teknik pengumpulan data yang digunakan dalam penelitian ini adalah data kuantitatif dan data kualitatif. Data kuantitatif diperoleh dari hasil observasi pembelajaran di kelas dan di sekolah, validasi terhadap media pembelajaran yang dikembangkan. Data kualitatif diperoleh dari hasil wawancara dan kuesioner tanggapan guru terhadap media pembelajaran yang dikembangkan. Pada penelitian dan pengembangan ini untuk menghasilkan produk Perangkat pembelajaran yang baik khususnya media pembelajaran dan layak digunakan maka dibutuhkan instrument pengumpulan data. Instrument pengumpulan data yang digunakan dalam penelitian ini berupa Lembar penilaian kelayakan Media Pembelajaran Berbasis kurikulum 2013 kelas IV Tema 9: Makananku Sehat dan Bergizi.

Teknik analisis data yang digunakan dalam penelitian ini dengan cara melakukan valiadasi instrument media pembelajaran kurikulum 2013 kelas IV tema makananku sehat dan bergizi. Hasil validasi dianalisis dengan mengikuti langkah-langkah analisis dalam penilaian instrument. Langkahlangkah yang digunakan dalam menganalisis data penilaian kelayakan perangkat media pembelajaran sebagai berikut: 1) Mentabulasi semua data hasil penilaian yang diperoleh dari validator dan untuk setiap komponen butir yang dinilai dalam instrument penilaian; 2) Menghitung skor total rata-rata setiap komponen dengan menggunakan rumus sebagai berikut: $\left.\quad \bar{X}=\frac{\Sigma X}{n} ; 3\right)$ Mengubah skor ratarata menjadi nilai dengan Kriteria yang digunakan dalam menganalisis instrument media pembelajaran.

\section{HASIL PENELITIAN DAN PEMBAHASAN}

Penelitian ini mengembangkan media pembelajaran berbasis kurikulum 2013 kelas IV dengan tema makananku sehat dan bergizi. Pada tema makananku sehat dan bergizi, peneliti mengambil satu subtema yaitu tema pertama tentang makananku sehat dan bergizi.

Peneliti melakukan validasi kepada pakar pendidikan untuk menilai apakah produk yang dihasilkan sudah baik atau kurang baik untuk diujikan. Peneliti melakukan validasi produk Media Pembelajaran Berbasis Kurikulum 2013. Validasi dilakukan oleh validator yang terdiri dari 3 pakar pendidikan dari dosen UKSW, 3 pakar pendidikan dari dosen luar UKSW, dan 3 praktisi (Guru Sekolah Dasar). Intrumen validasi media pembelajaran yang berupa rubrik penilaian tersebut menunjukkan hasil penskoran secara kuantitatif. Kriteria penskoran dalam rubrik penilaian ditentukan berdasarkan tabel sebagai berikut (Kemendikbud, 2014: 127):

Tabel 1.

Kriteria Peringkat Kualitas RPP berbasis Karakter

\begin{tabular}{ll}
\hline Peringkat & Nilai \\
\hline Amat Baik $(\mathrm{AB})$ & $90<\mathrm{AB}<100$ \\
\hline Baik $(\mathrm{B})$ & $80<\mathrm{B}<90$ \\
\hline Cukup $(\mathrm{C})$ & $70<\mathrm{C}<80$ \\
\hline Kurang $(\mathrm{K})$ & $\leq 70$ \\
\hline
\end{tabular}


Validasi produk dilakukan oleh 9 ahli pendidikan (3 dosen uksw, 3 dosen luar uksw, dan 3 guru sebagai praktisi) bertujuan untuk mengetahui kelayakan dan kualitas produk sebelum di uji cobakan, media pembelajaran berbasis kurikulum 2013 tema Makananku sehat dan bergizi pada subtema 1. Media pembelajaran berbasis kurikulum 2013 tema makananku sehat dan bergizi pada subtema 1 terdiri dari 6 pembelajaran. Masing-masing pembelajaran divalidasi dengan mengukur indikator dari media pembelajaran yaitu: jenis media yang digunakan, Kesesuaian materi dengan media dan Tampilan dari media tersebut. Berikut ini adalah hasil validasi media pembelajaran subtema 1:

Tabel 2.

Hasil Validasi Media Pembelajaran Subtema 1, Pembelajaran 1

\begin{tabular}{|c|c|c|c|c|c|c|c|c|c|}
\hline \multirow{2}{*}{ Indikator } & \multicolumn{9}{|c|}{$\Sigma$ dan $\%$ Validator } \\
\hline & 1 & 2 & 3 & 4 & 5 & 6 & 7 & 8 & 9 \\
\hline \multirow{2}{*}{ Jenis Media } & 25 & 23 & 23 & 20 & 20 & 20 & 25 & 24 & 20 \\
\hline & $(100)$ & $(92)$ & $(82)$ & $(80)$ & $(80)$ & $(80)$ & $(100)$ & $(96)$ & $(80)$ \\
\hline \multirow{2}{*}{ Materi } & 14 & 12 & 12 & 12 & 12 & 12 & 12 & 13 & 12 \\
\hline & $(93)$ & $(80)$ & $(80)$ & $(80)$ & $(80)$ & $(80)$ & $(80)$ & $(87)$ & $(80)$ \\
\hline \multirow{2}{*}{ Tampilan } & 8 & 7 & 6 & 10 & 10 & 8 & 8 & 8 & 8 \\
\hline & $(80)$ & $(70)$ & $(60)$ & $(100)$ & $(100)$ & $(80)$ & $(80)$ & $(80)$ & $(80)$ \\
\hline Rata-rata validator & 94 & 84 & 82 & 84 & 84 & 80 & 90 & 90 & 80 \\
\hline Rata-rata Total & & & & & 85,33 & & & & \\
\hline
\end{tabular}

Tabel 2 di atas menunjukan bahwa skor rata-rata hasil validasi yang diberikan validator praktisi $(1,2,3)$, validator ahli dari luar $\operatorname{UKSW}(4,5$, dan 6), validator ahli dari dalam $\operatorname{UKSW}(7,8$, 9) sebesar 85,33. Hal ini menunjukkan bahwa validasi Media Pembelajaran pada subtema "Makananku sehat dan bergizi" pembelajaran 1 berdasarkan indikator jenis media, materi, dan tampilan media berada pada kategori "Amat Baik".

Tabel 3.

Hasil Validasi Media Pembelajaran Subtema 1, Pembelajaran 2

\begin{tabular}{cccccccccc}
\hline Indikator & \multicolumn{10}{c}{$\boldsymbol{8}$ dan $\%$ Validator } \\
\cline { 2 - 12 } & $\mathbf{1}$ & $\mathbf{2}$ & $\mathbf{3}$ & $\mathbf{4}$ & $\mathbf{5}$ & $\mathbf{6}$ & $\mathbf{7}$ & $\mathbf{8}$ & $\mathbf{9}$ \\
\hline \multirow{2}{*}{ Jenis Media } & 25 & 24 & 21 & 22 & 22 & 20 & 20 & 20 & 17 \\
& $(100)$ & $(96)$ & $(84)$ & $(88)$ & $(88)$ & $(80)$ & $(80)$ & $(80)$ & $(68)$ \\
\hline \multirow{2}{*}{ Materi } & 13 & 15 & 12 & 15 & 15 & 12 & 12 & 12 & 11 \\
& $(87)$ & $(100)$ & $(80)$ & $(100)$ & $(100)$ & $(80)$ & $(80)$ & $(80)$ & $(73)$ \\
\hline \multirow{2}{*}{ Tampilan } & 13 & 15 & 12 & 15 & 15 & 12 & 12 & 12 & 11 \\
& $(87)$ & $(100)$ & $(80)$ & $(100)$ & $(100)$ & $(80)$ & $(80)$ & $(80)$ & 73 \\
\hline Rata-rata validator & 96 & 90 & 82 & 90 & 90 & 80 & 80 & 80 & 72 \\
\hline Rata-rata Total & & & & & $\mathbf{8 4 , 4 4}$ & & & & \\
\hline
\end{tabular}

Tabel 3 di atas menunjukan bahwa skor rata-rata hasil validasi yang diberikan validator praktisi, validator ahli dari luar UKSW, validator ahli dari dalam UKSW sebesar 84,44. Hal ini menunjukkan bahwa validasi Media Pembelajaran pada subtema "Makananku sehat dan bergizi" pembelajaran 2 berada pada kategori "Amat Baik".

Tabel 4.

Hasil Validasi Media Pembelajaran Subtema 1, Pembelajaran 3

\begin{tabular}{cccccccccc}
\hline \multirow{2}{*}{ Indikator } & \multicolumn{10}{c}{$\boldsymbol{8}$ dan $\%$ Validator } \\
\cline { 2 - 12 } & $\mathbf{1}$ & $\mathbf{2}$ & $\mathbf{3}$ & $\mathbf{4}$ & $\mathbf{5}$ & $\mathbf{6}$ & $\mathbf{7}$ & $\mathbf{8}$ & $\mathbf{9}$ \\
\hline \multirow{2}{*}{ Jenis Media } & 25 & 24 & 21 & 20 & 20 & 23 & 23 & 23 & 23 \\
& $(100)$ & $(96)$ & $(84)$ & $(80)$ & $(80)$ & $(92)$ & $(92)$ & $(92)$ & $(92)$ \\
\hline \multirow{2}{*}{ Materi } & 12 & 13 & 11 & 12 & 12 & 15 & 15 & 15 & 15 \\
& $(80)$ & $(87)$ & $(73)$ & $(80)$ & $(80)$ & $(100)$ & $(100)$ & $(100)$ & $(100)$ \\
\hline \multirow{2}{*}{ Tampilan } & 8 & 8 & 4 & 8 & 8 & 8 & 8 & 8 & 8 \\
& $(80)$ & $(80)$ & $(40)$ & $(80)$ & $(80)$ & $(80)$ & $(80)$ & $(80)$ & $(80)$ \\
\hline Rata-rata validator & 90 & 90 & 72 & 80 & 80 & 92 & 92 & 92 & 92 \\
\hline Rata-rata Total & & \multicolumn{7}{c}{$\mathbf{8 6 , 6 7}$} \\
\hline
\end{tabular}


Pengembangan Media Pembelajaran Kurikulum 2013 di Kelas IV Tema 9 Subtema 1

(Indri Anugraheni, Firosalia Kristin)

Tabel 4 di atas menunjukan bahwa skor rata-rata hasil validasi yang diberikan validator praktisi, validator ahli dari luar UKSW, validator ahli dari dalam UKSW sebesar 86,67. Hal ini menunjukkan bahwa validasi Media Pembelajaran pada subtema "Makananku sehat dan bergizi" pembelajaran 3 berada pada kategori "Amat Baik".

Tabel 5.

Hasil Validasi Media Pembelajaran Subtema 1, Pembelajaran 4

\begin{tabular}{|c|c|c|c|c|c|c|c|c|c|}
\hline \multirow{2}{*}{ Indikator } & \multicolumn{9}{|c|}{$\Sigma$ dan $\%$ Validator } \\
\hline & 1 & 2 & 3 & 4 & 5 & 6 & 7 & 8 & 9 \\
\hline \multirow{2}{*}{ Jenis Media } & 21 & 25 & 21 & 21 & 21 & 20 & 20 & 20 & 21 \\
\hline & $(84)$ & $(100)$ & $(84)$ & $(84)$ & $(84)$ & $(80)$ & $(80)$ & $(80)$ & $(84)$ \\
\hline \multirow{2}{*}{ Materi } & 15 & 13 & 12 & 12 & 12 & 12 & 9 & 12 & 15 \\
\hline & $(100)$ & $(87)$ & $(80)$ & $(80)$ & $(80)$ & $(80)$ & $(60)$ & $(80)$ & $(100)$ \\
\hline \multirow{2}{*}{ Tampilan } & 8 & 8 & 10 & 8 & 8 & 8 & 6 & 8 & 9 \\
\hline & $(80)$ & $(80)$ & $(100)$ & $(80)$ & $(80)$ & $(80)$ & $(60)$ & $(80)$ & $(90)$ \\
\hline Rata-rata validator & 88 & 92 & 86 & 82 & 82 & 80 & 70 & 80 & 90 \\
\hline Rata-rata Total & \multicolumn{9}{|c|}{83,33} \\
\hline
\end{tabular}

Tabel $5 \mathrm{di}$ atas menunjukan bahwa skor rata-rata hasil validasi yang diberikan validator praktisi, validator ahli dari luar UKSW, validator ahli dari dalam UKSW sebesar 83,33. Hal ini menunjukkan bahwa validasi Media Pembelajaran pada subtema "Makananku sehat dan bergizi" pembelajaran 4 berada pada kategori "Amat Baik".

Tabel 6.

Hasil Validasi Media Pembelajaran Subtema 1, Pembelajaran 5

\begin{tabular}{cccccccccc}
\hline \multirow{2}{*}{ Indikator } & \multicolumn{10}{c}{$\Sigma$ dan \% Validator } \\
\cline { 2 - 12 } & $\mathbf{1}$ & $\mathbf{2}$ & $\mathbf{3}$ & $\mathbf{4}$ & $\mathbf{5}$ & $\mathbf{6}$ & $\mathbf{7}$ & $\mathbf{8}$ & $\mathbf{9}$ \\
\hline \multirow{2}{*}{ Jenis Media } & 20 & 25 & 21 & 21 & 21 & 21 & 21 & 21 & 21 \\
& $(80)$ & $(100)$ & $(84)$ & $(84)$ & $(84)$ & $(84)$ & $(84)$ & $(84)$ & $(84)$ \\
\hline \multirow{2}{*}{ Materi } & 14 & 15 & 15 & 12 & 9 & 13 & 13 & 13 & 13 \\
& $(93)$ & $(100)$ & $(100)$ & $(80)$ & $(60)$ & $(87)$ & $(87)$ & $(87)$ & $(87)$ \\
\hline \multirow{2}{*}{ Tampilan } & 10 & 7 & 10 & 8 & 6 & 9 & 9 & 9 & 9 \\
& $(100)$ & $(70)$ & $(100)$ & $(80)$ & $(60)$ & $(90)$ & $(90)$ & $(90)$ & $(90)$ \\
\hline Rata-rata validator & 88 & 94 & 92 & 82 & 72 & 86 & 86 & 86 & 86 \\
\hline Rata-rata Total & & 8 & 85,78 & & & & \\
\hline
\end{tabular}

Tabel 6 di atas menunjukan bahwa skor rata-rata hasil validasi yang diberikan validator praktisi, validator ahli dari luar UKSW, validator ahli dari dalam UKSW sebesar 85,78. Hal ini menunjukkan bahwa validasi Media Pembelajaran pada subtema "Makananku sehat dan bergizi" pembelajaran 5 berada pada kategori "Amat Baik".

Tabel 7.

Hasil validasi Media Pembelajaran Subtema 1, Pembelajaran 6

\begin{tabular}{|c|c|c|c|c|c|c|c|c|c|}
\hline \multirow{2}{*}{ Indikator } & \multicolumn{9}{|c|}{$\Sigma$ dan $\%$ Validator } \\
\hline & 1 & 2 & 3 & 4 & 5 & 6 & 7 & 8 & 9 \\
\hline Jenis Media & $\begin{array}{c}25 \\
(100)\end{array}$ & $\begin{array}{c}24 \\
(96)\end{array}$ & $\begin{array}{c}20 \\
(80)\end{array}$ & $\begin{array}{c}20 \\
(80)\end{array}$ & $\begin{array}{c}20 \\
(80)\end{array}$ & $\begin{array}{c}20 \\
(80)\end{array}$ & $\begin{array}{c}23 \\
(92)\end{array}$ & $\begin{array}{c}20 \\
(80)\end{array}$ & $\begin{array}{c}20 \\
(80)\end{array}$ \\
\hline Materi & $\begin{array}{c}12 \\
(80)\end{array}$ & $\begin{array}{c}14 \\
(93)\end{array}$ & $\begin{array}{c}13 \\
(87)\end{array}$ & $\begin{array}{c}13 \\
(87)\end{array}$ & $\begin{array}{c}13 \\
(87)\end{array}$ & $\begin{array}{c}12 \\
(80)\end{array}$ & $\begin{array}{c}12 \\
(80)\end{array}$ & $\begin{array}{c}12 \\
(80)\end{array}$ & $\begin{array}{c}12 \\
(80)\end{array}$ \\
\hline Tampilan & $\begin{array}{c}9 \\
(90)\end{array}$ & $\begin{array}{c}8 \\
(80)\end{array}$ & $\begin{array}{c}8 \\
(80)\end{array}$ & $\begin{array}{c}8 \\
(80)\end{array}$ & $\begin{array}{c}8 \\
(80) \\
\end{array}$ & $\begin{array}{c}8 \\
(80)\end{array}$ & $\begin{array}{c}8 \\
(80)\end{array}$ & $\begin{array}{c}8 \\
(80)\end{array}$ & $\begin{array}{c}8 \\
(80) \\
\end{array}$ \\
\hline Rata-rata validator & 92 & 92 & 82 & 82 & 82 & 80 & 86 & 80 & 80 \\
\hline Rata-rata Total & & & & & 84,00 & & & & \\
\hline
\end{tabular}

Tabel $7 \mathrm{di}$ atas menunjukan bahwa skor rata-rata hasil validasi yang diberikan validator praktisi, validator ahli dari luar UKSW, validator ahli dari dalam UKSW sebesar 84,00 Hal 
ini menunjukkan bahwa validasi Media Pembelajaran pada subtema "Makananku sehat dan bergizi" pembelajaran 6 berada pada kategori "Amat Baik".

Berdasarkan hasil penelitian diatas dapat dijelaskan bahwa pengembangan media pembelajaran berbasis kurikulum 2013 berada pada kategori amat baik khususnya pada indikator jenis media yang digunakan, materi yang relevan dan sehingga dapat digunakan dalam proses pembelajaran di kelas. Media pembelajaran sangat diperlukan oleh guru untuk membantu supaya materi yang disampaikan ke siswa dapat mudah dipahami oleh siswa sehingga siswa tersebut dapat mengerti dan memahami apa yang disampaikan oleh guru. Pengembangan media pembelajaran dalam kurikulum 2013 diperlukan jenis media yang relevan dengan materi yang diajarkan, tampilan media pembelajaran juga penting untuk diperhatikan. Hal ini relevan dengan penelitian yang dilakukan oleh Hengkang Bara $(2015,61)$ yang menyatakan bahwa media pembelajaran (khususnya komik) yang dikembangkan berada pada kategori baik sehingga dapat digunakan dalam kegiatan pembelajaran. Sejalan dengan penelitian yang dilakukan Nur Sholichan (2017, 935) mwedia pembelajaran (khususnya Macromedia flash) yang dikembangkan sangat layak untuk digunakan sebagai alternative media pembelajaran kurikulum 2013.

\section{SIMPULAN DAN SARAN}

Berdasarkan hasil penelitian dan pembahasan, peneliti dapat menarik kesimpulan sebagai berikut: peneliti telah mengembangkan media pembelajaran kurikulum 2013 kelas IV tema makananku sehat dan bergisi pada subtema satu pembelajaran $1-6$. Media pembelajaran yang dikembangkan sangat layak untuk digunakan dalam kegiatan belajar mengajar di kelas. Berdasarkan hasil validasi dengan mengukur jenis media, materi yang relvan dan tampilan dari media secara menyeluruh memperoleh penilaian "Amat Baik". Hal ini membuktikan bahwa produk pengembangan yang dihasilkan berupa media pembelajaran kurikulum 2013 valid dan layak untuk digunakan dalam pembelajaran kelas IV.

Saran bagi penelitian selanjutnya adalah pemanfaatan, diseminasi, dan pengembangan lebih lanjut, juga disarankan bagi guru untuk dapat menggunakan media pembelajaran kurikulum 2013 di kelas Iv tema makanan sehat dan bergizi sebagai media inovatif. Media pembelajaran yang dikembangakan hanya pada tema makanan sehat dan bergizi, oleh karena itu perlu dikembangkan media pembelajaran dengan tema dan subtema yang lain. dalam rangka pemanfaatan media pembelajaran secara luas, maka perlu disosialisasikan kepada guru-guru atua sekolah-sekolah.

\section{DAFTAR PUSTAKA}

Alimuddin. 2014. Penilaian dalam Kurikulum 2013. Prosiding Seminar Nasional Pendidikan Karakter di Gedung SCC Palopo pada Sabtu, 03 Mei 2014. Diakses tanggal 28 Februari 2018, dari https://journal.uncp.ac.id/index.php/proceding/article/view/220/209

Batubara, H. H. (2018). Pengembangan Media Pembelajaran Matematika berbasis Android untuk Siswa SD/MI. Muallimuna: Jurnal Madrasah Ibtidaiyah, 3(1), 12-27.

Fransisca, I. (2018). Pengembangan Media Pembelajaran Video Berbasis Sparkol Videoscribe Pada Pelajaran Ipa Dalam Materi Tata Surya Kelas VI SD. Jurnal Penelitian Pendidikan Guru Sekolah Dasar, 6(11).

Kemendikbud. (2014). Materi Pelatihan Guru Implementasi Kurikulum 2013 Tahun 2014 SD kelas I. Jakarta: Depdikbud.

Lailiyah, N., \& Sukartiningsih, W. (2018). Pengembangan Media Pembelajaran Interaktif Berbasis Flash Untuk Pembelajaran Keterampilan Menuliskan Kembali Cerita Siswa Kelas IV SD. Jurnal Penelitian Pendidikan Guru Sekolah Dasar, 6(7).

Mawardi, M. (2018). Merancang Model dan Media Pembelajaran. Scholaria: Jurnal Pendidikan dan Kebudayaan, 8(1), 26-40.

Muhson, A. (2010). Pengembangan media pembelajaran berbasis teknologi informasi. Jurnal Pendidikan Akuntansi Indonesia, 8(2). 
Pengembangan Media Pembelajaran Kurikulum 2013 di Kelas IV Tema 9 Subtema 1

(Indri Anugraheni, Firosalia Kristin)

Nurus Sholichah, Y. Y. (2017). Pengembangan Media Pembelajaran Berbasis Macromedia Flash Dengan Menerapkan Pendekatan Saintifik Untuk Meningkatkan Pemahaman Konsep Mata Pelajaran Ipa Kelas V Sdn Kebraon 1/436 Surabaya. Jurnal Penelitian Pendidikan Guru Sekolah Dasar, 5(3).

Saputro, H. B., \& Soeharto, S. (2015). Pengembangan media komik berbasis pendidikan karakter pada pembelajaran tematik-integratif kelas IV SD. Jurnal Prima Edukasia, 3(1), 61-72.

Saputro, R. E., \& Saputra, D. I. S. (2015). Pengembangan Media Pembelajaran Mengenal Organ Pencernaan Manusia Menggunakan Teknologi Augmented Reality. Jurnal Buana Informatika, 6(2).

Sitepu, B.P. (2012). Penulisan Buku Teks Pelajaran. Bandung: PT Remaja Rosdakarya.

Sugiyono. (2010). Metode penelitian pendidikan. Bandung: Alfabeta

Trianto. (2010). Model Pembelajran Terpadu. Jakarta: Bumi Aksara 